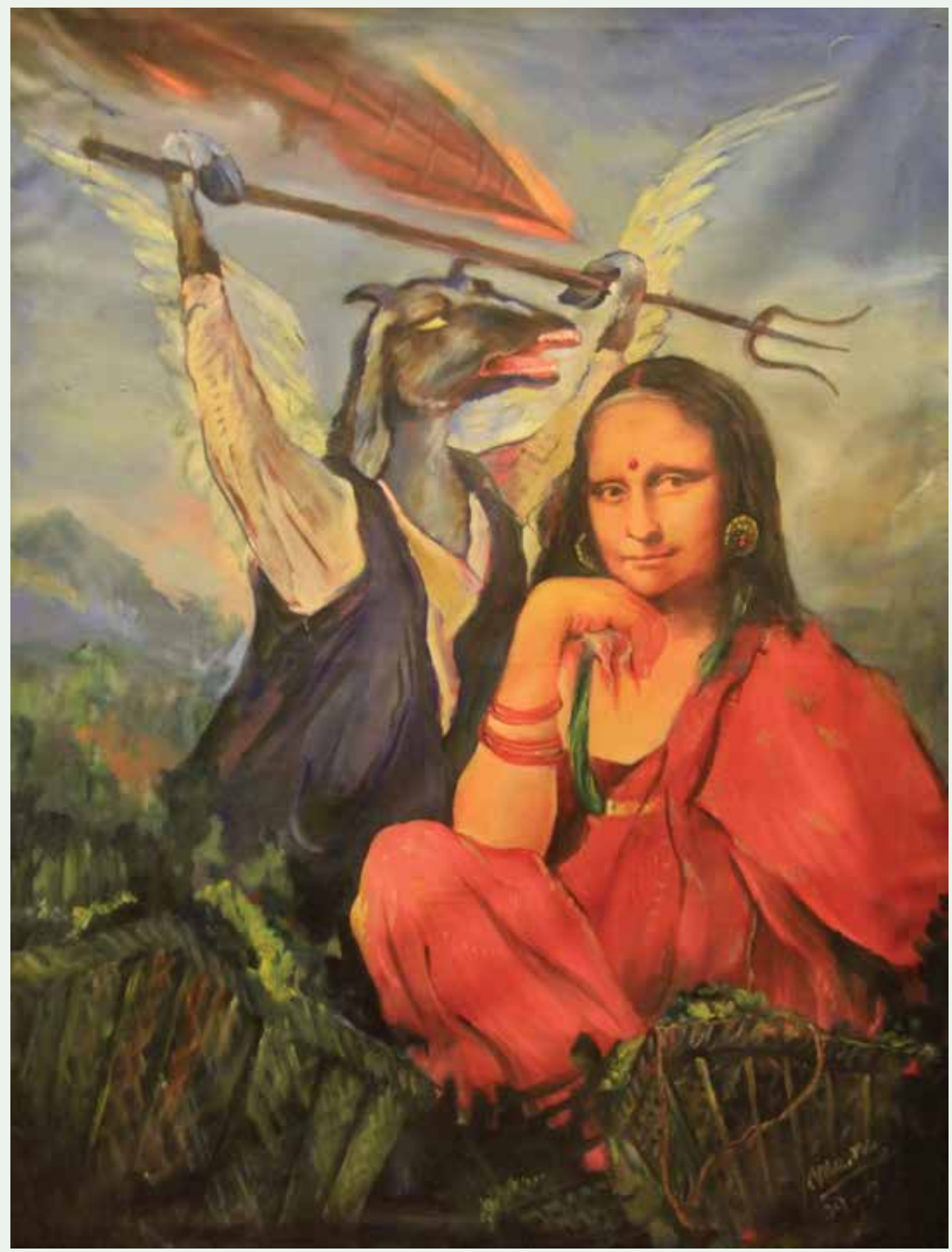

Manuj Babu Mishra, 'Monalisa', 2009. Oil on canvas. (Photo courtesy: Roshan Mishra) 


\title{
MY UNDERSTANDING OF MANUJ BABU AND HIS ART
}

\author{
DR. ABHI SUBEDI
}

\begin{abstract}
Manuj Babu Mishra (1936-2018) was a modern artist who is mainly known for his paintings and his drawings. Nepali art critic Narayan Bahadur Singh as early as 1976 mentioned about his multiple skills in art. But Mishra was also one of those painters who ushered in an era of modern consciousness shared equally by painters and poets. His contemporaries some of whom are still painting though on a smaller scale, made experiments with their arts in modernist style. An era of distorting forms, breaking the fine figurality and using flatness by shunning the illusion of three dimensional shapes rather than representative forms was seen in Nepali modernist paintings too. Manuj Babu Mishra adopted a method of using figurality in paintings that used semi surrealistic and abstract paintings. Mishra was trained in Dhaka of the then East Pakistan in the late sixties of the last century. Despite his political statements occasionally, he was basically an artist. He was a peaceful man behind the hurricanes of hard times he created. He was also a portraitist who believed that the portrait of a person is also the portrait of the world outside him or her. He had said that to me when he was drawing my portrait.
\end{abstract}

Narayan Bahadur Singh (1930-1987), probably the only serious and authentic Nepali art historian and critic, in his most cited and loved book of Nepali art history Samasaamayik Nepali Chitrakalako Itihas (1976) or 'the history of the contemporary Nepali art', has presented the first vignette of the modern painter Manuj Babu Mishra (1936-2018). I think it is very appropriate to present the main observations of Singh about Mishra's art because in a genre where there was/is scant mention, let alone review of Nepali artists and their works, to cite the views of this critic would be important from a historical and dynamic perspective of Nepali art historicism.

Singh says, Manuj Babu experiments with diverse styles. One can still see the impact of his training in his art (Singh 248). He works in both oil and water mediums. His art ranges from realism to cubism. He works on various mediums like lithograph, dry point, etching, wood engraving and cut, apart from painting. He makes still life paintings, landscapes, and human portraits. Manuj Babu appears realistic in such works, but he appears 
to be shifting to modernist art. The forms of his modernism include the distorted figurality such as the elongation of human forms. But he is basically drawn by the cubist style of Pablo Picasso. By using blue and green, he creates the intense effect of human misery. Such paintings look almost monochromatic when he uses one of these predominantly. These paintings perhaps reflect the hard life he had to live after his parents' death when he was young (249).

Singh's observation written so many years ago indicates at the evolution of Manuj Babu's paintings. In a rare review of the modernist Nepali paintings available at that time, Singh's observations put life and objectivity or impersonality of the artist and art together. Impersonality of the painter or of a poet was beginning to emerge. I want to cite from one of my reviews here in the context of this debate. One historical exhibition of paintings by one modernist artist and poet Uttam Nepali in Kathmandu brought this matter in visual and tangible form. I want to cite from my review of that exhibition published several years back:

It was the very exhibition of paintings in which an abstract artist chose to transform the nature of reading into a different medium. The lines in the canvas some viewers told me then did interrupt the sense of artistic perceptions by creating disturbances on the eye path; the lines were creating discordant effects in the harmony and tonality of colours in the paintings and they dominated the spirit of the paintings. But the main point of interest at this time in Nepali modernism in both poetry and painting was that both painters like Bangdel, Uttam Nepali and the SKIB, an acronym for artists Sashi Shah, Krishna Manandhar, Indra Pradhan and Batsa Gopal Vaidya, and poets whose lines did Uttam Nepali include in his paintings were going through a similar experience in the realms of creative arts. During that period poets wrote abstract poems, painters produced abstract works, and singers included multi dimensional forms, words and symphony in their music. I am especially alluding to the works of the doyen of Nepali music Ambar Gurung. Uttam Nepali's paintings executed on the themes of the poets like Iswor Ballabh, Tulasi Diwasa, Bairagi Kanhila, Madan Regmi, Banira Giri, Bashu Shashi, Mohan Koirala, Krishna Bhakta Shrestha, Dwarika Shrestha, Kali Prasad Rijal, Upendra Shrestha, Mohan Himanshu Thapa and Bhupi Sherchan precisely mark the mood of his period. (Subedi, "Writers' Portraits and..)

Though I have not mentioned Manuj Babu Mishra, he was around. The other point of interest is that he was a literary writer also who wrote creative essays, and in later times, wrote fiction. In a recent online article about modernist Nepali 
painters I have indicated at Manuj Babu's method of blending moods and techniques, and his sensitivity to the changes brought by times. This shows how Manuj Babu has gained maturity in his art since Singh wrote the above review. I closely knew Manuj Babu Mishra whose paintings as I will explain in my essay cited below, are experimental, and obtrusive in which apocalyptic vision dominates the works. I have written recently, "The forms that are visibly distorted, contorted and stylised show his modus operandi that clearly foregrounds the picture of the modern era, or of modernism, which is haunted. But the scary figurality, human heads pierced by jets including his own, pythons rising to the sky and the domination of blue and green, as well as dark, ironically represent a calm acquired after a catharsis. Mishra is also a portraitist. He has drawn one of mine, which is included in his book of paintings. I feel immensely delighted by that, especially by the fact that he has kept my figurality outside the surreal modus opernadi (Subedi, "Modern Nepali").

The words 'seclusion', 'hermitage', haunting image, are related to the evolution of Manuj Babu's art. I published an obituary under the title "Manuj Babu, turbulence and peace", in the Kantipur daily. To avoid repetition I would like to present the free rendering of that essay putting additional necessary notes in that process:

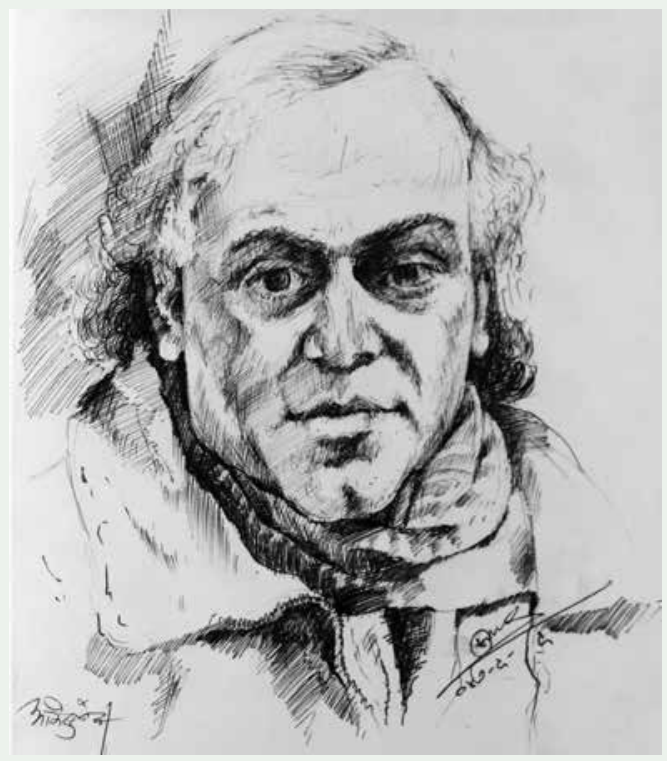

Manuj Babu Mishra, A Portrait Study of Abhi Subedi, 1990. Pen and ink on paper. (Photo Courtesy: In the Eye of the Storm: Drawings of Manuj Babu Mishra,

Published by Nepal Investment Bank, 2009.)

There is one family house that looks like Gandhi's Sabarmati Ashram, near the Bouddha Monastery. A small house for the family to live, a few shades and a cottage of Nepali style with mud smeared walls and atmosphere created by that. That is the space of Manuj Babu Mishra. He calls that small cottage "hermitage", the meaning of which is a place where you sit for meditation, a retreat where he created a world that he imagined, and a picture of the days to come. These creations are paintings and drawings. The motif of this quiet man is hurricane. This peaceful man created an aura of disquietude and loud noise around him. Sky is crowded with speedy missiles. Huge ferocious pythons and snakes rise and 


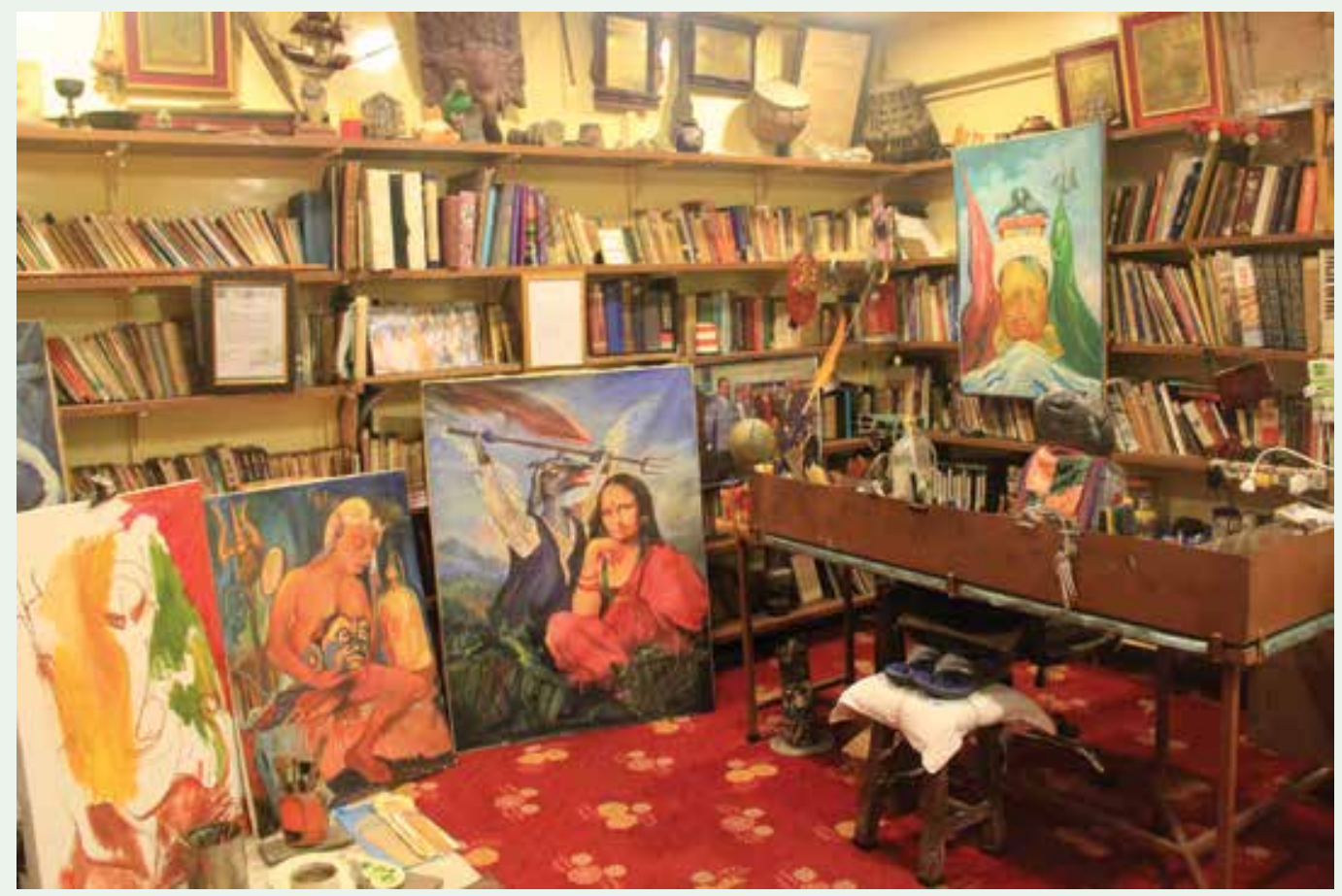

Studio of Manuj Babu Mishra - 'Hermitage', Bouddha. (Photo Courtesy: Roshan Mishra)

fly in the sky. In the first view itself one understands the motifs are the human beings traumatised by snake bites, the penetrating missiles carrying bombs, and the artilleries. Green, yellow, blue and also some white and black colours or pigments used in the paintings depict the miseries experienced by the human beings in their world growing dismal.

Manuj Babu comfortably assumes a large than life avatar and takes all this creation with him without qualms. However, Manuj Babu did not believe that the creator of the ferocious art and the life of the creator were different. He created missiles passing through the artist's head. The paradox is that the artist is in the world and lives a normal life like everyone else. In this manner Manuj Babu had used the turbulence and noise as the rhythm of his artist's life. But the turbulent moments and the grand peace that he had found within this did not go with him when he made his final exit on 8 August 2018. They are scattered all over the Hermitage and the rest of the world, and in the self-portraits of the artist.

We cannot understand Manuj Babu by using the ferocious motif of his paintings. We should also try to understand the context and condition of his education. Art curator and art critic Sangeeta Thapa who has 


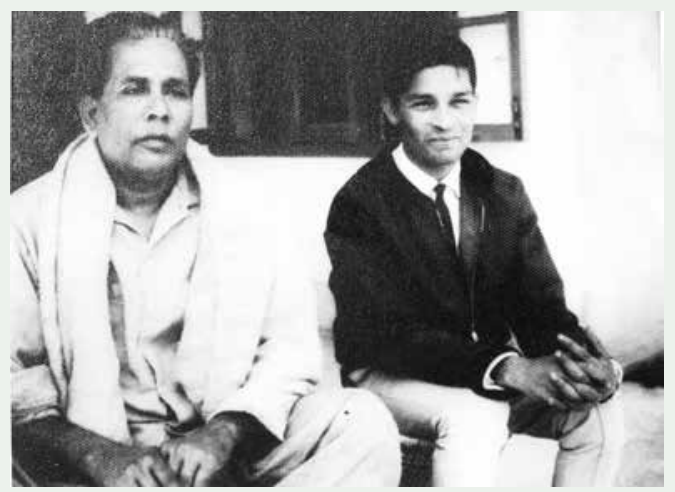

Manuj Babu Mishra with his guru Zainul Abedin in Dhaka, c.1960s.

prepared a book of Manuj Babu's paintings with a brilliant long introduction entitled "Drawings of Manuj Babu Mishra" (2009) believes that to properly appreciate the artist's works we should understand the place of his education and the impact of his gurus and artists on his work.

Manuj Babu's art education in Dhaka of the then East Pakistan from 1963-68, plus another six months' special training, shaped him as an artist. The lingering memories of the Great Bengal Famine that he shared in literary writings there, the difficulties of the quotidian life, and the miseries of the people and their visual impressions that he saw left deep impact on Mishra's mind. Sangeeta Thapa sees the influence of Ganesh Pyne's paintings in Manuj Babu. Pyne was one "proponent of the Bengal School" in art. In Pyne's works, "Man is presented as a vanquished breed; they are killers, and areevil personified" (Thapa IX). Thapa reveals another important influence, and that was of Zainul Abedin (191878) who "was a founder of Dhaka Arts College". This guru "taught in Government School of Art in, where, incidentally, the late Lain Singh Bangdel was one of his students" (Thapa VIII). As Abedin belonged to the "Neo-Bengal School", it would be very interesting to see the tradition of art education in India that trained Nepali artists. This subject requires a long and carefully researched article that is not possible to do here.

But I feel it important to recall an experience that I had when I visited Bangladesh, Dhaka in a couple of decades of the emergence of Bangladesh, another memory working strongly. At that stage artists and writers were recalling their horrid experience of the time of the killings and displacement of people during the freedom struggle. I was surprised to see the exaggerative use of the expressionism of motifs, style and colours in their paintings. I also met some elderly teachers and artists. When two professors of English at Dhaka University and art critics Syed Manjarul Islam and Kaiser Haq, introduced me to the senior artists, and explained the art works, I felt I was seeing another dimension of Manuj Babu's art apprenticeship in that country.

Manuj Babu's fierce looking paintings are his art works. Though he glibly entered the world of his art, and presented himself as a victim in the 


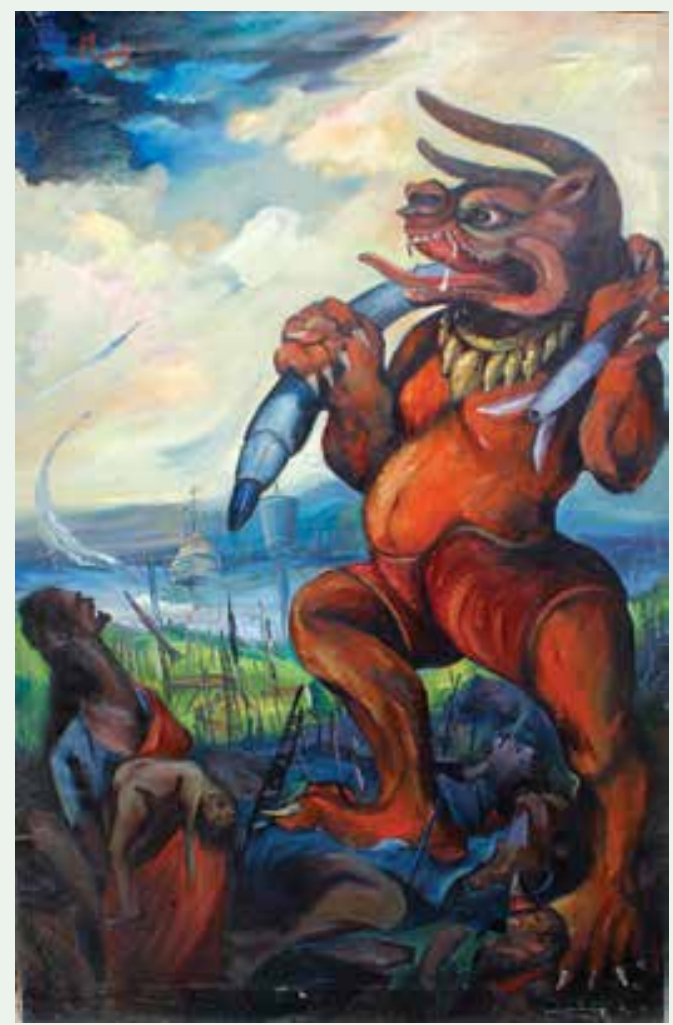

Manuj Babu Mishra, Untitled, 1982. Oil on canvas. (Photo Courtesy: Roshan Mishra)

boisterous world of his art, he kept himself at a distance from that larger than life experience in the same way as Picasso was detached from the theme of his painting of Guernica city destroyed by German bombs, just as the sixteenth century Italian painter Caravaggio kept himself detached from his violent paintings, just as the Nepali painter Lain Bangdel was detached from the paintings that he executed under the influence of Picasso's blue period paintings. The nineteenth century Spanish painter Francis Goya's paintings give the violent image of human beings.
The English painter Francis Bacon, similarly, makes terrifying visages of human beings. There are many examples. In all these, we can say that no Nepali painters were similar to Manuj Babu in the choice of themes and use of techniques.

It would be interesting to recall one experience here. One day Manuj Babu was making a painting on his veranda and I was watching him. Disproportionate and scary images were coming up there, while we could hear the sound of a masked dance of the famously known Lakhe ritual, loved by children and adults alike coming from the Bouddha side in the quietness that used to be the feature of the environment those days. Manuj Babu without raising his head from his work said, "Abhi, do you know? Children get frightened by the mask and the dance of this Lakhe; I don't let them go to see it." Manuj Babu was making a far more fearful painting than anything that the zero mask of a repeated festival could match. I realised that day, there was a great rare calm behind this artists' ferocious and intensely loud paintings. There was a moment of great calm as seen by the Buddha. I knew he was creating the self same power of calm behind the scary art, and the salvation of mankind behind a world where missiles carrying atomic weapons were flying.

Though Manuj Babu was quite senior to me in age, I never addressed him as 


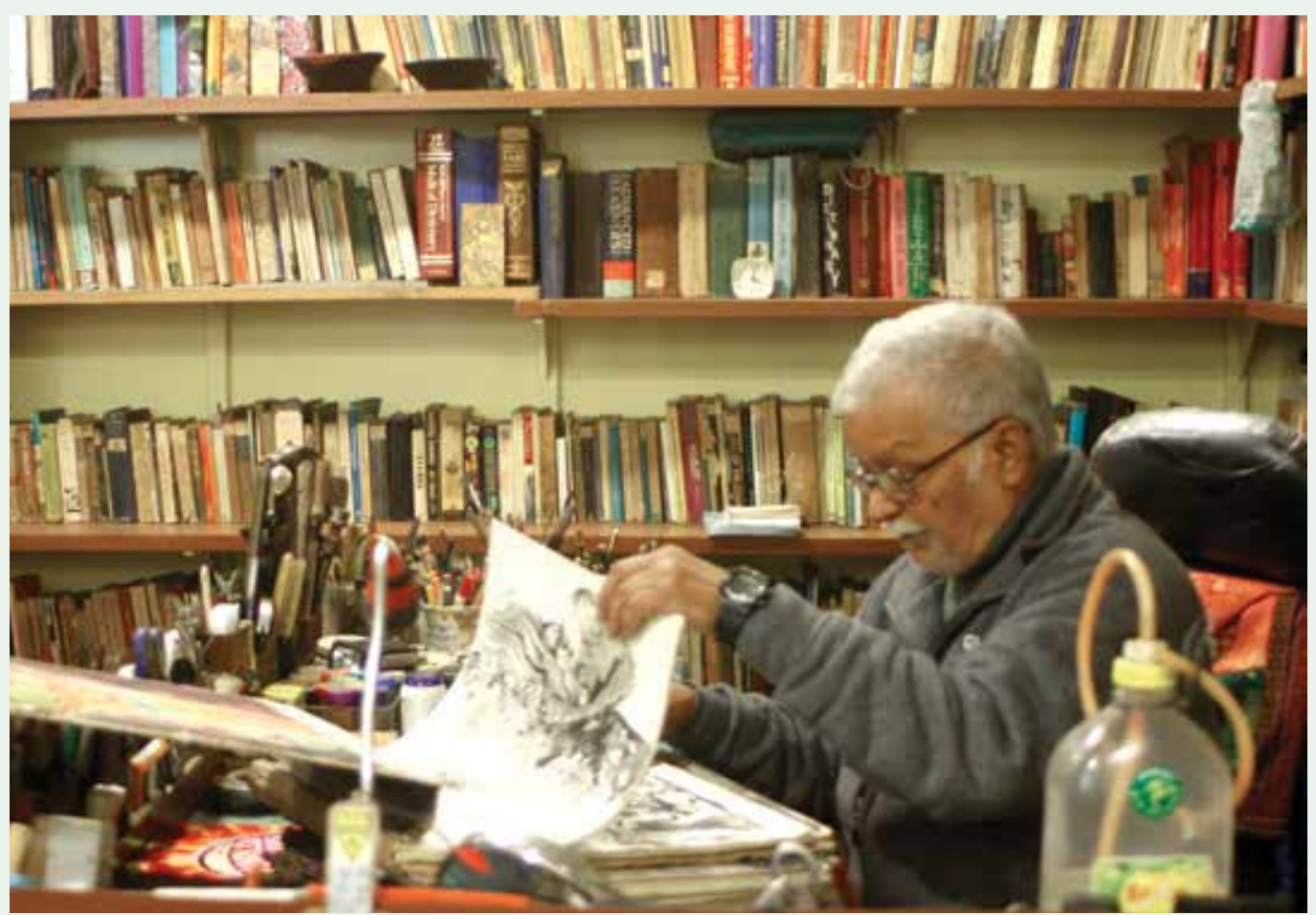

Manuj Babu Mishra in his studio - 'Hermitage', Bouddha, 2016. (Photo Courtesy: Bijaya Maharjan)

dai or elder brother, which is a practice among us, the literary writers. This Hermitage was a place that I visited alone or with like minded friends so many times, stayed for hours and returned. At such moments I heard Manuj Babu speaking about his philosophy of life and the purpose of his art. It is always a sense of joy and liberation to see the working space of painters. I have experience of visiting the working spaces of several artists, like Lain Singh Bangdel's working space upstairs, Bala Krishna Sama's painting room adjacent to his drawing room, Amar Chitrakar's naturally created calm and inspiring working corner, Uttam Nepali's painting corner cluttered with canvases and paintings, Kiran Manandhar's small Atelier at the foot of Swoyambhu hill and his caves and sunny spaces in his house of Tahachal. Whenever the textures of lines, colours, sizes of finished and dripping canvases come to my mind, I feel a sense of creative strength for my own work of a different medium. Such spaces leave impact on the minds of the visitors who are close to the artists. The working places of artists are like livid dramatic stages made with forms and colours where the artists dialogued, quarrelled and made peace with their own lives. We can see their moments of crises and happiness in such mise 


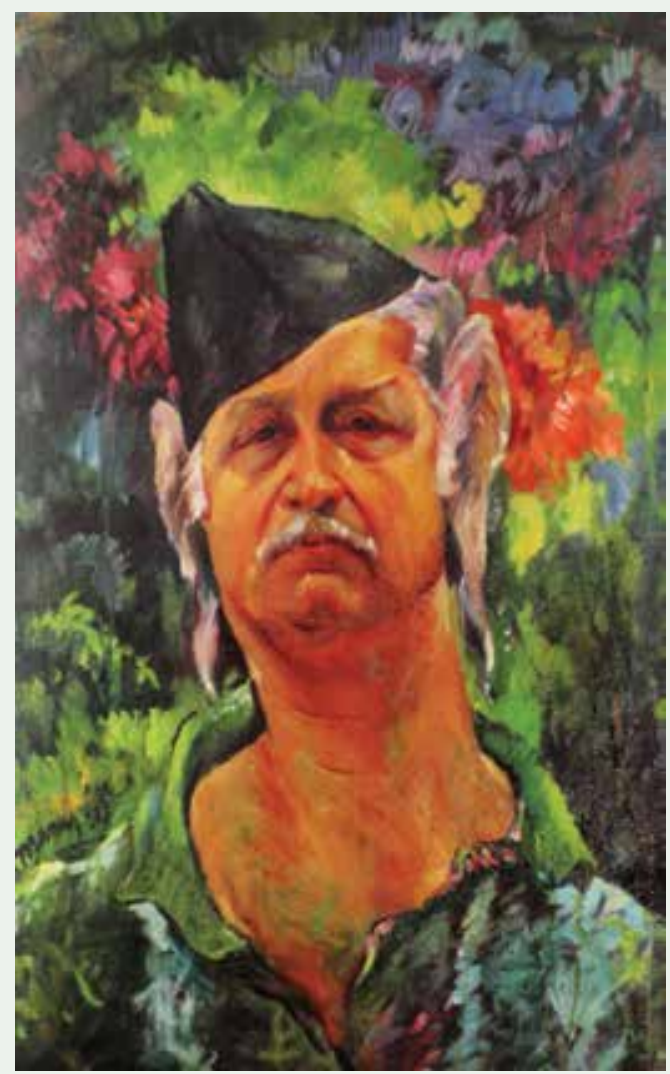

Manuj Babu Mishra, Self portrait, 2002. Oil on canvas. (Photo Courtesy: Roshan Mishra)

on scene. I also saw several spaces of Western and Japanese artists. But the one I saw in Marseilles of France has struck me deeply. That is Cézanne's secluded working space, in a small house overlooking the Mediterranean Sea where he moved with a socalled lower class woman, to avoid the society's gossips. Like Manuj, Cezanne had moved to the seclusion of his own choice. That was Cezanne's Hermitage.

I also had literary connection with Manuj Babu. He was an essayist who wrote mostly on big themes that involved knowledge, science and art subjects. He was also an academic who has written a book about the history of art. Though he wrote stories and fictions, he preferred to be known as an artist. He was indeed an artist par excellence. But those of us who were close to him saw another side of his personality too. That was his political self. Manuj Babu never accepted the democratic change of 1990 in Nepal. In fact, he was so frustrated by that change that he wanted to retreat from the active world and spend his time with his own creative works in seclusion named Hermitage. He had said to me then, a friend had sent him a book from Germany the subject of which, he said, if I remember correctly, was promoting radical thoughts. I did not give any importance to this shift of Manuj Babu because I believed and still believe that these were the expressions of the moments of discontent of an artist immersed in his art, sometimes without 'objective correlative.' His philosophy emanate from his style and philosophy, not from the engaged knowledge of active politics with clear goals to fulfil.

Manuj Babu and I had topics of common interest like the interpretation of art, human condition, his moments of discoveries while executing people's portraits, the success achieved by his son Rabindra Mishra, my very close erstwhile student, at the BBC, and many more. 
I must confess, I do not have more space to discuss about Manuj Babu Mishra's craft, which requires careful attention and appreciation. But in conclusion what I can say is that behind the fearsome forms of his art one can feel his ability to understand human nature and various moments of existence, and that ability is poetic.

I have one very revealing moment to share. One day, in one of my visits to his house, he wanted to draw my portrait. I sat in front of him talking. After working for sometime, he rejected that and started to do another portrait. I asked him why he had cancelled the first. I felt deep down the power of his art when he said, "the face of a person, and that also of a writer, is a flow, a movement. It is not just the face, but the outer world also that the artist should be able to capture in that portrait". The 'world' reflected in my portrait that he has "included" in the book Drawings of Manuj Babu Mishra, is a poem that I have not yet been able to decode fully.

I returned after paying my last tribute to him at Pashupati carrying with me the perennial dialogic tension between language and colours.

\section{References}

Subedi, Abhi. "Writers' Portraits and Joys of Voyeurism" Across, January - March 2003. Vol 6.No. 4.Pp 9-13.

Subedi, Abhi. "Modern Nepali Art: Bangdel and after as mirrored in my reviews" http://www.bikalpaartcenter.org/ modern-nepali-art-abhi-subedi/
Subedi, Abhi. "Manuj Babu, kolahalra shanti". Kantipur. August 11, 2018.

Thapa, Sangita. Ed. With Introduction. In the Eye of the Storm: Drawings of Manuj Babu Mishra. Kathmandu: Nepal Investment Bank, 2009.

Singh, Narayan Bahadur. Samasaamayik Nepali Chitrakalako Itihas. Kathmandu: Nepal Rajakiya Pragya Pratishthan, 1976.

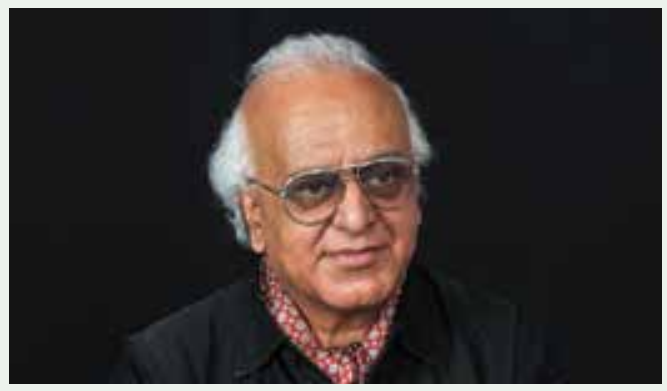

\section{Dr. Abhi Subedi}

Born in Terathum of eastern Nepal, Dr. Abhi Subedi received his higher education in Nepal and Britain. He is an essayist, critic, linguist, playwright and poet. He has over two-dozen books on different subjects to his credit. Among his over 10 plays, strong theatre groups in Nepal and abroad have performed several of theme.

Professor Subedi has taught 43 years at the Central Department of English.

He has written extensively about Nepali arts and artists. He is involved in a number of interdisciplinary study groups and a prolific writer on issues of freedom, culture, literature, arts and social transformations. His essays and seminar papers are published in Nepal and outside. 